\title{
The Use of Psychological Correction Programs to Improve the Occupational Fitness of Correctional Personnel
}

\author{
IRINA. N. MININA \\ Pskov State University, Pskov, Russian Federation \\ ORCID: https://orcid.org/0000-0001-6240-4834, e-mail: irimin@rambler.ru \\ DIANA YA. GRIBANOVA \\ Pskov State University, Pskov, Russian Federation, \\ ORCID: https://orcid.org/0000-0002-5633-5876, e-mail: dianab81@mail.ru
}

\begin{abstract}
Introduction: the article examines the results of the application of a short-term psychological correction program, which includes conflict prevention and the development of adaptive behavior skills in difficult communication situations. Aim: based on the results of the study, to identify conditions for the effective use of psychological programs to overcome stress among prison staff. Methods: the tasks set in the work were solved with the help of general scientific research methods within the framework of comparative, statistical and logical analysis and empirical methods such as description and interpretation of the information. The study involved 80 employees of the security department of correctional institutions of the Pskov Oblast, divided into experimental and control groups. The trainings were conducted by full-time psychologists of the departments. To assess the effectiveness, we used the following methods: "Willpower self-assessment scale" by N.N. Obozov, the technique for determining the level of neuropsychic stability "Forecast", and the questionnaire of interpersonal relations in the adaptation of W. Shchutz. Results: the analysis of the data with the help of mathematical statistics methods has shown that the use of such programs is advisable among employees included in the group of increased attention. These may be persons conditionally recommended for this type of activity, as well as those who have been subjected to the deforming influence of an unfavorable professional environment. A statistically significant result for the experimental group of subjects consisted in a change in the indicators on the sincerity scale, which can mean an increase in self-esteem, trust in the psychologist and the desire to answer the questions honestly. The greatest effectiveness of the training was observed when we were implementing the tested program; this is explained by increased motivation and responsibility for its results. No practical effect of participation in the training was revealed among the personnel who initially had indicators that did not require correction. Conclusions: in order to increase the effectiveness of trainings, it is necessary that psychologists have personal conscious motivation when they work out unique programs that take into account actual needs of correctional staff.

Ke y w o r d s : psychological correction program; psychological support of personnel; willpower; stress; mental stability; training; group of increased attention.

19.00.06 - Legal psychology.

For citation: Minina I.N., Gribanova D.Ya. The use of psychological correction programs to improve the occupational fitness of correctional personnel. Penitentiary Science, 2021, vol. 15, no. 3 (55), pp. 669-676. DOI 10.46741/2686-9764-2021-15-3-669-676.
\end{abstract}

\section{Introduction}

The effectiveness of penitentiary institutions depends on the level of occupational fitness of their personnel, who traditionally belong to the category of persons with a high level of emotional load and stress. Having reviewed domes- tic and foreign literature we identify the most significant correlates of work stress among employees of pre-trial detention centers and prisons. Unjustified workload, hypervisibility, perception of staff shortage, problems of social roles, insufficient control, autonomy, lack 
of support at work or at home, exposure to violence by convicts were most associated with increased stress among prison security personnel. In high-security correctional institutions, the main professional stress factors include a higher level of violence on the part of prisoners and the ratio of employees to convicts, in which there is a greater number of prisoners per warden $[1 ; 3 ; 7 ; 10 ; 13 ; 14 ; 17]$. Besides, a multilevel analysis of the impact of work stress conducted on a sample of 1,800 prison employees working in 45 U.S. prisons has shown that the assumed control over prisoners, support from colleagues and superiors contributed to the reduction of professional stress [16].

Staff suitability is based on professional qualities, which include individual-mental and personal qualities of an individual, necessary and sufficient for self-realization in the chosen profession. Successful professionalization is facilitated by the presence of work experience and the desire to perform official duties at a decent level. Numerous studies in different countries confirm a significant relationship between organizational justice and professional performance of employees of the law enforcement system [18]. Justice can be called one of the main principles of the humanistic system of values and all human life activity. The employee's subjective assessment of the fairness of the relations is a significant factor that affects professional motivation.

The average image of a candidate whom the penal enforcement system wants to see in its ranks is an emotionally mature, calm, selfpossessed person from 18 to 40 years old, who does not succumb to random mood fluctuations, is able to withstand considerable physical and emotional loads, flexible in interpersonal interaction, inclined to compromise. E.I. Kokorina studied the factors contributing to professional and psychological suitability of candidates for service in the penal system and, according to the results of psychological diagnostics at the Military Physician Board of Occupational Health Facility-12 of FSIN Russia in 2016, revealed that about 33\% of them do not have such qualities [3, p. 447].

When studying the issues of professional suitability of a specialist, it is necessary to take into account the individual data of a person, their motivation and appropriate professional training.

According to Article 17 of Federal Law 197FZ of July 19, 2018 "On the service in the penal system of the Russian Federation and on amendments to the Law of the Russian Fed- eration "On institutions and bodies executing criminal penalties in the form of imprisonment", citizens who are "able to perform official duties of an employee by their personal and business qualities, physical fitness and health status" can enter the service. Establishing the compliance of these qualities and personality traits of the candidate with the approved requirements is the main task of professional psychological selection. A.M. Rakov notes that the employer's refusal to hire a candidate protects the candidate from the psycho-emotional load that is too much for them, and protects society from the negative consequences of professional insolvency of the future employee. At the same time, this selection ensures legal validity of the appointment of the most suitable candidate to the position, determines the qualities and characteristics that should be taken into account and monitored in the process of professional development [1, p. 104].

In recent decades, two approaches to the criteria of professional psychological selection have remained unchanged:

1. Identification and screening of candidates with extremely unfavorable socio-psychological, individual-psychological or psycho-physiological characteristics (selection according to the minimum requirements).

2. Identification and selection of candidates for the service who meet the requirements for professionally important qualities as much as possible (selection according to the maximum of requirements) [1, p. 108].

To ensure the effectiveness of the service, the second approach is the optimal one. It gives the opportunity to choose the best of the candidates undergoing the selection procedure. But such an approach is possible to implement in institutions where there is no urgency of staffing, no staff turnover, and a significant number of candidates want to enter the service there.

Currently, objective circumstances dictate the implementation of the first approach in the selection of candidates for the service in the penal system; the first approach is aimed at preventing professional breakdown among personnel. These conditions lead to the recruitment of persons who, according to the results of professional and psychological selection, fall under the wording "conditionally recommended". The leadership of the Federal Penitentiary Service of Russia focuses on the need for timely prevention of destructive phenomena among the personnel of institutions and bodies executing punishments [8, pp. 3-4]. 
The discrepancy between individual psychological qualities and specific labor requirements in the penal system contributes to the emergence of mental overstrain in young employees and, as a result, various psychosomatic disorders and diseases. This leads to dissatisfaction with the official position and the chosen profession.

The phenomenon of job satisfaction is associated with many positive results, such as increased labor productivity, organizational commitment, reduced professional burnout, and reduced staff turnover. Studies in the United States, Europe and China convincingly show that indicators of working environment factors explain a greater share of variance in the indicator of job satisfaction than personal characteristics such as gender, term of office, religion, marital status, age and level of education. The participation of correctional personnel in decision-making and the diversity of professions had significant positive associations, while occupational hazard had a significant negative relationship with the indicators of satisfaction with the performed official activity [11-13].

Psychologists in correctional institutions should promote successful adaptation of employees. The set of psychological impact tools contains programs aimed at changing nonadaptive individual psychological qualities of a person. Psychological correction technologies help an employee to become aware of their usual ineffective ways of responding and, based on the conscious and experienced personal material, to form the ability to solve their problems more effectively, adapt and realize themselves in professional activities and personal life [9, p. 38].

According to a study by Polish colleagues [15], in which they analyzed the role of personality, organizational factors and strategies for overcoming stress in the formation of job satisfaction, social sensitivity is a predictor of a positive attitude of correctional officers, correctional and rehabilitation personnel and administration toward their work. This personal quality is closely related to the development of reflection in an adult. And the strongest predictor they studied was the motivation of leadership and power, since in correctional institutions its implementation by staff is easily achievable, as well as legally, psychologically and pedagogically justified.

American psychologists also point out the importance of social control in prison life. Thus, the satisfaction of prison staff with their work in it depends on the control they exercise over prisoners, as well as the exercise of authority over them. The irony of these conclusions lies in the fact that those factors that positively correlate with the satisfaction with the work of prison staff have opposite consequences and, accordingly, a negative correlation with the vector of perception of the conditions of serving a sentence by convicts [12].

\section{Methods}

The analysis of the practice of psychological work in the penal system shows that the most relevant psychological correction measure for the prevention of professional burnout is training employees in methods of conscious psychological self-regulation, including autogenic and ideomotor training, neuromuscular relaxation, techniques of sensory reproduction of images, elements of suggestion, etc. [10, pp. 157-158]. Despite the proven importance of organizational factors in reducing occupational stress, penitentiary psychologists can hardly influence the variables of the working environment.

At the All-Russian Symposium of Psychologists held at the Academy of FSIN Russia in 2019, it was noted that penitentiary psychologists of the territorial bodies of FSIN Russia should not only report, but also analyze the effectiveness of the influence of psychological correction programs on the personality of employees of the penal system and convicts [7, p. 129].

In order to introduce psychological tools for the prevention of undesirable mental states and correction of employees' personal qualities, psychologists at the Directorate of FSIN Russia in the Pskov Oblast in the period from December 2019 to March 2020 implemented a short-term program of psychological correction, including conflict prevention and the development of skills and abilities of adaptive behavior in difficult communication situations. According to the results of the program, it was supposed to increase psychological stability of the psycho-emotional state in the personnel of territorial correctional institutions in the region.

In the course of the work, the following tasks were addressed:

- identification of personal qualities and conditions that require corrective action. For this purpose, psychological tests were selected and the diagnosis of the level of severity of the studied characteristics was carried out;

- development of a short-term program for psychological correction by selecting training 
methods that can be implemented among employees of the penal system in correctional institutions;

- testing of the program by conducting training in an experimental group of employees;

- repeated testing of the studied personal characteristics of the respondents from the experimental and control groups and statistical processing of the results obtained.

In total, 80 male and female employees from four correctional institutions of FSIN Russia in the Pskov Oblast took part in the study of the effectiveness of the program. The experimental and control groups consisted of 40 people of mixed gender composition, since the functional responsibilities of the respondents did not take into account these differences.

Before participating in the training events, the personnel were tested using the following techniques: "Willpower self-assessment scale" by N.N. Obozov, assessment of neuropsychic stability "Forecast" developed at Saint Petersburg Military Medical Academy and the interpersonal relations questionnaire (Fundamental Interpersonal Relations Orientation, FIRO) adapted by W. Shchutz.

\section{Results}

According to the results of the correlation analysis of the input testing indicators for all respondents, reliable relationships were revealed between the auxiliary scale that assesses sincerity $L$ and the scales of willpower $(r=0.27$; $p<0.01)$ and neuropsychic stability $(r=0.29$; $\mathrm{p}<0.01)$. This suggests that employees who have mental qualities required for the service in the penal system are more inclined to control the information they receive and position their behavior as socially approved.

A direct correlation between neuropsychiatric stability and the main indicators of the FIRO methodology - "Inclusion" $(r=0.35 ; p<0.01)$ and "Affection" $(r=0.35 ; p<0.01)$ - was significantly manifested. Mentally stable employees are able to participate in a wide range of interactions with various groups and remain unaffected. The more valuable and significant an employee feels himself to be, the higher their resistance to various influences of subjects of interpersonal interaction. Behavior that corresponds to the need for emotional connections in groups indicates the establishment of friendly relations and differentiation between group members. Such people strive to create and maintain a sense of warm emotional relationship. However, these personal characteristics can provoke the establishment of off-duty rela- tions of staff with convicts, as well as difficulties in transferring employees to other departments in the interests of the service.

The short-term program for correctional and developmental classes "Reduction of negative emotional states of employees of the security department in the performance of official duties" (hereinafter - the program) developed by O.V. Potapova, head of the psychological laboratory of Correctional Colony-4, at the first stage included exercises aimed at removing blocks and creating comfortable, positive relationships in the group. At the second stage, classes were held to develop the skills of confident, effective communication in the service, develop the skills to analyze one's own condition, search for a positive way out of various situations. The third stage of the training was focused on the formation of self-confidence, emotional stability, determination and self-control in the participants when communicating with convicts. The exercises were aimed at reducing aggressiveness and developing strongwilled stability. The final stage of the program was devoted to teaching the skills of focusing on the reactions of one's own body and working out various ways of self-regulation.

The training activities were implemented in January - February 2020 by full-time psychologists of correctional institutions, who also processed the results of initial and control testing. Statistical processing of the results was carried out by the Department of Psychology and Child Development Support at Pskov State University with the use of SPSS Statistics software.

In general, according to the results of the study using the Wilcoxon signed-rank test, the short-term program had no significant effect on willpower and neuropsychic stability of those participating in the training (40 people). This result can be explained by fairly high estimates of these indicators that do not require correction among the majority of respondents who entered the service after successfully passing psychological tests. The average values on the willpower self-assessment scale in the experimental group were $7.8 \pm 1.6$ sthenes, in the control group - 6.8 \pm 1.9 sthenes. However, among the seven participants with relatively low test results from 4 to 6 sthenes, after completing the program, five showed an increase in the arithmetic mean from 5.14 to 6.29 sthenes.

Almost all the results obtained using the "Forecast" technique indicate that penal officers have good or sufficient neuropsychiatric stability. The average values before the 
implementation of the program were about 6 sthenes, and the difference in subsequent control measurements did not exceed 1 sthene.

However, a significant difference was revealed in the measurements for the auxiliary indicator $L$ (the scale of sincerity). An empirical value of -3.218 was obtained, with the significance level of the criterion $p<0.001$. Low values on this scale indicate that the subject honestly answered questions and was self-confident.

Thus, after the implementation of the Program in the experimental group, there was a change in the indicators on the sincerity scale from $5.53 \pm 1.9$ to $4.5 \pm 2.1$ sthenes, which may mean an increase in self-esteem and the desire to answer the questions honestly. Such results are possible with an increase in the trust in the psychologist and a decrease in the desire of respondents to appear better than they really are. Often, high indicators on this scale among law enforcement officers indicate increased requirements for their behavior rather that the unreliability of the results.

Modern science knows only isolated cases of experimental verification of lie scales for the reliability and validity of measurements. In particular, A.Yu. Myagkov mentions a study by N.M. Bradburn and S. Sudman (1979), who tried to answer the question whether the scale of the need for social approval really measures exactly the latent variable for which it was created at the time. As a result of the validation experiment, they came to the conclusion that high scores on the test results are shown not only by respondents who are really inclined to social desirability, but also by people who have high moral standards and strictly follow conventional norms in everyday life. The authors summarize that, consequently, the deception scale to a greater extent shows actual personal characteristics of individuals, the specifics of their lifestyle, consciousness and behavior, rather than the subjects' inclination to distort the answers to the given questions [6, p. 66].

In any case, the change in the indicator under consideration is a positive result, since it indirectly shows a decrease in mental stress among correctional officers.

In the indicator of neuropsychiatric stability, its main psychophysiological correlates are of great importance, they include the strength and balance of nervous processes, the speed and accuracy of a complex visual-motor reaction, the tone of the sympathetic division of the autonomic nervous system, the value of the cardiointerval [4, p. 4]. It is almost impossible to influence them in the short term. Therefore, in order to change the psychological correlates of neuropsychic stability, which include thinking, beliefs, worldview, etc. a longer period and qualitatively different development technologies are required.

During the experiment, the changes in interpersonal relationships were studied using the FIRO questionnaire. According to the results, two indices were formed: "Volume of interactions" and "Inconsistency of interpersonal behavior".

The normal functioning of an individual requires a balance in three areas of interpersonal needs between the individual and the people around them. Therefore, the respondents' preferred intensity of contacts was studied, as well as the gap between their own behavior and the behavior they require from others; the increase in this gap provokes internal conflicts and frustration in the field of interpersonal relations.

There was no significant influence of the short-term program on the characteristics within and between individual areas of interpersonal needs of all those participating in the training (40 people).

When considering the results of the program on 20 employees of the experimental group with the initial values of the "Inconsistency" index over 5 points (the probability of internal conflict), a decrease in the average values of the indicators from 7.25 to 5.25 points (by $28 \%$ ) was revealed. However, in the control group, among employees with initial values of the "Inconsistency" index over 5 points (22 people), the average indicator also decreased from 6.5 to 5.1 points $(21 \%)$. Perhaps the change in these characteristics is not related to the practical effect of employees' participation in the training.

In the course of the program, there was the strengthening of the interrelationships of willpower and neuropsychic stability indicators in the experimental group $(r=0.4 ; p<0.01)$. This indicates that the exercises within the program potentially influenced the personal characteristics under consideration. The relationship between the sincerity scale and the "Required inclusion" scale of the FIRO technique was revealed. The higher the need to be noticed and heard, the more open the employee is in answering questions and the more trusting the employee is in their relations with the psychologist. Also, the alarming relationship between the indicators of neuropsychic stability and the need for differentiation and close emotional relationships has disappeared. 
During primary statistical processing of the results of the experiment, a hypothesis was made about the influence of personal and professional qualities of the trainer psychologist on the effectiveness of the program [5, p. 95]. Therefore, the results obtained during the experiment in Correctional Colony-4 were investigated, because the short-term program of correctional and developmental training under consideration was developed by the staff psychologist of this very institution.

In this division, according to the indicators of the willpower scale, all participants from the experimental group (10 people) after the training showed an increase in the average values from $7.3 \pm 1.5$ sthenes to $8.6 \pm 0.7$ sthenes; in the control group (10 people) almost everything remained unchanged: $6.8 \pm 1.2$ vs. $6.9 \pm 1.2$ sthenes.

According to the indicators of neuropsychiatric stability in the experimental group, all respondents showed an increase in the average values from $6.4 \pm 0.5$ to $6.9 \pm 0.3$ sthenes; practically nothing changed in the control group: $6.3 \pm 0.5$ vs. $6.4 \pm 0.7$ sthenes. The sincerity index in the experimental group improved from $5.1 \pm 0.9$ to $3.3 \pm 1.3$ sthenes; it worsened from $4 \pm 1.1$ to $4.6 \pm 1.1$ sthenes in the control group.

In other territorial divisions, the program did not have such significant results on the psychoemotional state of employees.

Thus, the goal of our study has been achieved, the assumption about the effectiveness of the program aimed at increasing the psychological stability of the psycho-emotional state of the personnel has been partially confirmed. There is a possibility that if the staff psychologist of Correctional Colony-4, who regularly improves her professional qualifications, would conduct trainings in all correctional institutions of the region, then the effectiveness of the tested shortterm program for correcting the indicators of willpower self-assessment and neuropsychic stability among all personnel would be higher and statistically significant.

\section{Conclusion}

Currently, the main work of psychologists of correctional institutions with their personnel includes diagnostic procedures when employing candidates for the service and psychological support of professional activities. Although psychological correction is one of the main regulated activities of psychologists in the penal system, conducting such events is rather an exception to the rules than a daily job. This is facilitated by the insufficient number of staff psy- chologists throughout the entire history of the creation and functioning of the psychological service. According to the authoritative opinion of M.G. Debolskii, although the minimum staff number of two psychologists in psychological laboratories "does not allow conducting psychological support of the work with convicts and staff in full, but it makes it possible to address the most urgent psychological issues that complicate the operational situation in the institution" [2, p. 126].

Taking into account the need for an appropriate distribution of the working time of staff psychologists, we can recommend carrying out psychological correction measures among the employees with reduced indicators of willpower and neuropsychic stability, that is, in a group of increased attention.

The results of the experimental implementation of the program have shown that its effectiveness depends more on the professionalism and motivation of the practicing psychologist and their interest in its results. Therefore, in order to increase the effectiveness of psychological support for the activities of employees of the Federal Penitentiary Service of Russia, we can recommend that psychologists undergo training in additional professional education programs. It may be useful to use financial incentives for participation in professional skill competitions.

In developed foreign countries, the number of staff psychologists involved in the psychological support of employees is significantly greater. Programs and strategies are being developed so as to deal with stress among correctional officers; during the testing and implementation of such programs, stress experts can provide assistance in adjusting or improving stress programs. Thus, when implementing this psychological tool in the territory of the state of Washington (USA), the U.S. Department of Justice recommended that several factors be taken into account in order to make its programs effective. For example:

- involvement of talented and dedicated psychologists who will withstand the stress of helping other employees who are experiencing it;

- ensuring the sincere participation of senior management, trade union and line managers, as well as family members of employees who need psychological help and correction of their mental states;

- maintaining confidentiality in their work;

- when providing services, the work should be done on a system-wide basis and not only 
after some critical incidents when the situation requires analysis;

- training managers to identify employees who may be experiencing stress and need psychological advice;

- if necessary, change the position or correctional institution in such a way as to reduce the employee's stress;

- monitoring program activities and evaluating their effectiveness in reducing stress and improving the efficiency of the unit [14, p. 129].

In 2014, at the 2014 National Symposium on Corrections Worker Health in the United States, leading experts from health authorities and justice departments noted that, despite significant local efforts and recommended best practices, there is no developed universal program for prison staff with proven effectiveness and safety. Therefore, additional research is needed in the field of well-being, physical and psychological health of employees working with convicts [17].

Thus, the dissemination of best practices of psychological correction activities carried out among the staff of correctional institutions is possible only when psychologists get acquainted with the recommended training measures and apply them consciously and voluntarily. The forced introduction of other people's developments cannot provide a guaranteed positive result. These events should motivate psychologists to develop unique programs that take into account the real needs of correctional personnel.

\section{REFERENCES}

1. Bovin B.G., Rakov A.M. Professional psychological selection in the penal system of Russia and its effectiveness. Prikladnaya yuridicheskaya psikhologiya=Applied Legal Psychology, 2009, no. 2, pp. 104-114. (In Russ.).

2. Debol'skii M.G. Psychological service of the penal system of Russia: the experience of organization. Rossiiskii psikhologicheskii zhurnal=Russian Psychological Journal, 2004, no. 1, pp. 119-130. Available at: https://www.elibrary.ru/ download/elibrary 16344754 14186837.pdf (accessed July 12, 2020). (In Russian).

3. Kokorina E.I. Professional psychological suitability of candidates for service in the penal system. Novalnfo.Ru, 2017, no. 65, pp. 444-447. Available at: https://novainfo.ru/pdf/065-1.pdf (accessed July 12, 2020). (In Russian).

4. Korzunin A.V. Psikhofiziologicheskie kriterii otsenki nervno-psikhicheskoi ustoichivosti $v$ protsesse voennoprofessional'noi adaptatsii voennosluzhashchikh: avtoreferat dissertatsii na soiskanie uchenoi stepeni kandidata meditsinskikh nauk [Psychophysiological criteria for the assessment of neuropsychological stability in the process of military professional adaptation: Candidate of Sciences (Medicine) dissertation abstract]. Saint Petersburg, 2015. 24 p. 5. Krasnenkova S.A. On the issue of the current state of psychological correction work in penitentiary practice. Prikladnaya yuridicheskaya psikhologiya=Applied Legal Psychology, 2008, no. 4, pp. 93-98. (In Russ.).

6. Myagkov A.Yu. Falsehood scales: the attempt of sociological reinterpretation. Vestnik IGEU=Vestnik of Ivanovo State Power University, 2006, no. 1, pp. 66-73. Available at: https://cyberleninka.ru/article/n/shkaly-Izhi-opyt-sotsiologicheskoyreinterpretatsii (accessed July 13, 2020). (In Russ.).

7. Ovcharova E.V. Modern psychological correction and psychotherapeutic directions in the work of penitentiary psychologists. In: Psikhologiya XXI veka: vyzovy, poiski, vektory razvitiya: tezisy dokladov vserossiiskogo simpoziuma psikhologov (Ryazan', 5 aprelya 2019 g.) [Psychology of the 21st century: challenges, search, vectors of development: Abstracts of the All-Russian Symposium of Psychologists (Ryazan, April 5, 2019)]. Ryazan: Akademiya FSIN Rossii, 2019. Pp. 125-129. Available at: https://www.elibrary.ru/item.asp?id=37275422\& (accessed July 17, 2020). (In Russ.).

8. Features of the organization and prospects for the development of psychological work with the personnel of the penal system within the framework of the implementation of the provisions of the Concept for development of the penal system of the Russian Federation until 2020: decision of the Board of the Federal Penitentiary Service of Russia. In: Ob ob"yavlenii reshenii kollegii Federal'noi sluzhby ispolneniya nakazanii: prikaz FSIN Rossii ot 07.12.2012 [On the announcement of decisions of the boards of the Federal Penitentiary Service: Order of FSIN Russia dated December 7, 2012]. (In Russ.).

9. Fedorova E.M. The main forms and methods of psychological prevention and correction of professional destruction of correctional personnel. Vedomosti ugolovno-ispolnitel'noi sistemy=News of the Penal System, 2016, no. 4 (167), pp. 3439. Available at: https://www.elibrary.ru/download/elibrary_26470782_20126321.pdf (accessed July 10, 2020). (In Russ.). 10. Cherkasova M.A. Psikhologicheskii monitoring professional'nogo vygoraniya sotrudnikov UIS Rossii: dissertatsiya na soiskanie uchenoi stepeni kandidata psikhologicheskikh nauk: 19.00.06 [Psychological monitoring of professional burnout of employees the penal system of Russia: Candidate of Sciences (Psychology) dissertation]. Vologda, 2014. 187 p.

11. Jiang S., Lambert E.G., Liu J., Zhang J. An exploratory study of the effects of work environment variables on job satisfaction among Chinese prison staff. International Journal of Offender Therapy and Comparative Criminology, 2018, vol. 62 (6), pp. 1694-1719.

12. Blau Ju.R., Light S.C., Chamlin M. Individual and contextual effects on stress and job satisfaction: a study of prison staff. Work and Occupations, 1986, vol. 13(1), pp. 131-156. DOI: 10.1177/0730888486013001009.

13. Ellison J. M., Caudill J.W. Working on local time: testing the job-demand-control-support model of stress with jail officers. Journal of Criminal Justice, 2020, vol. 70 (C). DOI: 10.1016 / j.jcrimjus.2020.101717.

14. Finn P. Addressing correctional officer stress: programs and strategies. Washington, DC: U.S. Department of Justice. 2000. Available at: https://files.eric.ed.gov/fulltext/ED449457.pdf (accessed January 9, 2021).

15. Sygit-Kowalkowska E., Poklek R., Pastwa-Wojciechowska B. Predicting the role of personality traits, organizational factors, and strategies for coping with stress in job satisfaction in correctional services. Polish Psychological Bulletin, 2020, vol. 50, pp. 275-283. DOI: 10.24425/ppb.2019.130701.

16. Steiner B., Wooldredge J. Individual and environmental sources of work stress among prison officers. Criminal Justice and Behavior, 2015, vol. 42 (8), pp. 800-818. DOI: 10.1177 / 0093854814564463. 
17. Elliot D., Kuehl K., El Ghaziri M., Cherniack M. Stress and corrections: addressing the safety and well-being of correctional officers. Corrections Today, 2015, vol. 77 (4), pp. 40-44.

18. Wolfe S.E., Lawson S.G. The organizational justice effect among criminal justice employees: a meta analysis. Criminology, 2020, vol. 58 (2). DOI: 10.1111 / 1745-9125.12251.

\section{INFORMATION ABOUT THE AUTHORS}

IRINA N. MININA - Candidate of Sciences (Psychology), associate professor of the Department of Psychology and Child Development Support at Pskov State University, Pskov, Russian Federation, ORCID: https://orcid.org/0000-0001-62404834, e-mail: irimin@rambler.ru.

DIANA YA. GRIBANOVA - Candidate of Sciences (Psychology), associate professor of the Department of Psychology and Child Development Support at Pskov State University, Pskov, Russian Federation, ORCID: https://orcid.org/0000-00025633-5876, e-mail: dianab81@mail.ru

Received August 10, 2020 